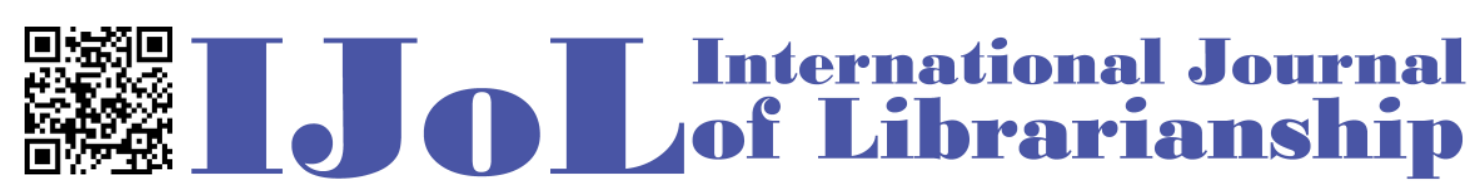

ISSN: 2474-3542 Journal homepage: http://journal.calaijol.org

\title{
From a Divided Library in a Divided City to One Library in Two Houses: A Centennial for a Great European Research Library Reunited and Restored
}

\author{
Daniel William Kinney
}

\begin{abstract}
:
The Berlin State Library-Prussian Cultural Heritage Foundation probably suffered more from the vicissitudes of the twentieth century than any other German cultural institution. It experienced the destruction of the building and the evacuation and loss of collections. Like Berlin, it was divided after World War II and was reunited after Berlin was reunited. In 2018, the library marks a century since the establishment of the Prussian State Library. But the legacy of the past century remains. Significant collections are still held in Eastern European libraries and the library must undertake the restitution of books acquired directly or indirectly through Nazi persecution. This article draws upon resources written in German and English to present the story of an important library that was under duress for much of the twentieth century. It discusses the impact of different historical eras on the library as a cultural institution and on the documentary heritage embodied in the library's rich collections. Although problems caused by these events remain, with reunification and restoration, the library is once again serving international scholarship and preserving an important part of the world's documentary heritage.
\end{abstract}

To cite this article:

Kinney, D.W. (2018). From a divided library in a divided city to one library in two houses: A centennial for a great European research library reunited and restored. International Journal of Librarianship, 3(2), 36-52.

To submit your article to this journal:

Go to http://ojs.calaijol.org/index.php/ijol/about/submissions 


\title{
From a Divided Library in a Divided City to One Library in Two Houses: A Centennial for a Great European Research Library Reunited and Restored
}

\author{
Daniel William Kinney \\ Stony Brook University, Stony Brook, NY, USA
}

\begin{abstract}
The Berlin State Library_-Prussian Cultural Heritage Foundation probably suffered more from the vicissitudes of the twentieth century than any other German cultural institution. It experienced the destruction of the building and the evacuation and loss of collections. Like Berlin, it was divided after World War II and was reunited after Berlin was reunited. In 2018, the library marks a century since the establishment of the Prussian State Library. But the legacy of the past century remains. Significant collections are still held in Eastern European libraries and the library must undertake the restitution of books acquired directly or indirectly through Nazi persecution. This article draws upon resources written in German and English to present the story of an important library that was under duress for much of the twentieth century. It discusses the impact of different historical eras on the library as a cultural institution and on the documentary heritage embodied in the library's rich collections. Although problems caused by these events remain, with reunification and restoration, the library is once again serving international scholarship and preserving an important part of the world's documentary heritage.
\end{abstract}

Keywords: Research Libraries, Germany, Berlin, International Librarianship

January 1, 2017 marked the twenty-fifth anniversary of the Berlin State Library-Prussian Cultural Heritage Foundation and the reunification of the former Prussian State Library, which during the Cold War was split into two separate libraries: the German State Library in East Berlin and the State Library, Prussian Cultural Heritage Foundation in West Berlin. Peter Whitehead (1976), who was a zoologist at the Natural History Museum, London, wrote that before the war, Berlin, together with Paris and London housed one of the very great European libraries (p. 7). The reunification of the former Prussian State Library ended almost half a century of division brought about by the devastation of the Second World War and the division of Berlin during the Cold War. Hans Stimmann (1997), former secretary of the Berlin Senate's Department for Urban Development, Environmental Protection, and Technology, wrote that nothing epitomizes more the deep-seated and difficult division of Germany and Berlin than the history of the Berlin State Library in the twentieth century (p. 75). In 1992, the East and West Berlin libraries became one library in two houses. The story of the Berlin State Library is the story of a phoenix among European research libraries. It rose from the ashes of World War II, survived the Cold War and the Berlin Wall, and, with the reunification of Germany and Berlin, returned to its former status as the largest research library in German-speaking lands. The events of the past hundred years have affected the library as a cultural heritage institution as 
well as the world's documentary heritage embodied in the library's collections. The account that follows tells the story of the survival of a great European research library threatened by the tumultuous events and social upheaval of the twentieth century. It remains a timely example of the troubled fortunes of the world's cultural and documentary heritage in countries and regions ravaged by war and conflict.

\section{HISTORICAL OVERVIEW (1661-1945)}

The former Prussian State Library was founded in 1661 and was known as the Library of the Elector until 1701 when it became the Royal Library. In the nineteenth century, Prussia began to place great importance on education. Wilhelm von Humboldt understood that libraries were essential to research and scholarship and he considered the Royal Library the central scholarly institute of his planned Berlin University (Kunze \& Dube, 1961, p. 22). A new library building on Unter den Linden in the center of Berlin, which was considered "the best and most beautiful library building in the world," (Richards, 1984, p. 233) was dedicated in 1914 in the last royal ceremony before the First World War. After the abdication of Kaiser Wilhelm II in 1918 until the defeat of the Third Reich in 1945, the library was known as the Prussian State Library. Before the Nazi seizure of power, the Prussian State Library had a worldwide reputation based on its collections and services. The list of eminent librarians that served in the library has been described as a "hall of fame of librarianship" (Reichmann, 1962, p. 225). It had become the world-class library demanded by the great classicist and Nobel Prize winner Theodor Mommsen in speeches given before the Prussian House of Representatives in the 1870s (Mommsen, 1905).

The Third Reich (1933-1945) was a dark period in the library's history. Located in the capital city, the Prussian State Library was the dominant library in the nation and it was closely controlled by the Nazi Party. During the Third Reich, German libraries were subject to Nazi racial laws and ideology. The passage of a civil service law for the professions in 1933 required that library staff of non-Aryan descent or staff who were political opponents of National Socialism be dismissed. Georg Leyh, director of the University Library at Tubingen, characterized the impact of the law as a "moral earthquake" (Dosa, 1974, p. 59). As a result of this law, "many eminent librarians were harassed, demoted, dismissed, or imprisoned" (Dosa, 1974, p. 60).

The trauma caused to the library by the Nazis and the war would last for decades. In a report written in 1947, Leyh describes the destruction and devastation of German libraries as a catastrophe without comparison in the history of knowledge and the history of libraries (p. 5). Klaus-Dieter Lehmann (1997), former president of the Prussian Cultural Heritage Foundation, noted that no other cultural establishment in Germany suffered so long and intensively as the Prussian State Library. Almost three hundred years of tradition were shattered by bombing raids in 1944 (p. 59). These traditions had enabled the library to develop world-famous special collections of incunabula, manuscripts, rare books, and especially music materials and to assume a leadership role in German librarianship and library education. The library was first struck by a bomb on April 9, 1941. The damage to the building was not extensive, but it made the library administration very aware of the danger to the library's collections. During World War II, the library's collections were sent to thirty storage depots for safety from air raids. Approximately 850,000 volumes, almost 30 percent of the library's print collection, never returned to the library from storage (Schochow, 2003, p. 307). The Berlin State Library estimates that about 335,000 volumes, including the alphabetical book catalog, were destroyed (Breslau, 1995, p. 8). 
Richard S. Hill, a reference librarian in the Music Division of the Library of Congress, wrote about the condition of the library building after visiting Berlin in June 1946. He reported that the library was hit by ten big bombs and innumerable fire bombs (p. 327). The worst damage was done on February 16, 1944 when a bomb hit the center of the building:

o The bomb came through the dome over the big, circular reading room, plunged unimpeded through the equivalent of six or seven open stories, and cut through three stack levels under the floor of the room. The explosion blew out half of the dome, and opened up three huge, roughly concentric rings in the successive floors of the stacks, leaving twisted remnants of the steel shelving showing as the rings get smaller at each descending level. It looks like a gruesome architect's model, with sections excised to show the construction within (Hill, 1946, p. 328).

The same air raid left the Music Division's reading room unusable. Damage to the library from other air raids included the destruction of the Incunabula Division, a large, triangular slice taken out of the building, and a rent in the ceiling through which the sky could be seen (Hill, 1946, p. 328-329). As Hill notes, had the library not evacuated its collections, the damage would have been "incalculable" (p. 328). Marta L. Dosa states: "Most of those who witnessed this devastation were convinced that the library had lost its leading position for decades to come" (Dosa, 1974, p. 167).

It was not until the present century that the damage done during the Second World War was repaired. The corner stone for the rebuilding of the library on Unter den Linden was laid in April 2006, and the topping-out ceremony for the library took place in February 2008. In March 2013 the new general reading room was opened, and in July 2013, the restored frame of the cupula over the main entrance that was destroyed in the air raid in 1941was crowned with a wreath. After three-quarters of a century, the restored historic building once again graces the heart of Berlin. The architectural firm of H. G. Merz won an international competition in 2000 for the restoration of the building on Unter den Linden and the rebuilding of the reading room. Merz designed a glass cube to replace the original octagonal reading room. Light is an important element in the design of the reading room, which has been described as a "light cube." The building on Unter den Linden can once again assume its historical reputation as the "cathedral of knowledge" (Kress-Adams and Adams, 2013, p. 51). Images of the original reading room and the new reading room are on the library's website (http://staatsbibliothekberlin.de/).

\section{THE COLD WAR ERA}

Despite extensive damage to the building and the loss of collections and staff, the former Prussian State Library reopened on October 1, 1946 in East Berlin under the name Public Research Library. Rudolf Hoecker, who had previously worked in the Periodicals Division of the Prussian Sate Library and served as director of the Berlin University Library from 1930 until 1933, became the director. The Nazis forced Hoecker to resign from his position as director of the University Library because he was a member of the Social Democratic Party, which ultimately made him particularly acceptable to the Soviets (Hill, 1946, p. 330). The library on Unter den Linden was renamed the German State Library in 1954. During the years of the German Democratic Republic (1949-1990), the German State Library in East Berlin was once again dominated by political ideology: its mission was to serve the socialist society (Kunze, 1961, p. 73). The library's new mission was symbolized by Werner Stötzer's bronze 
relief entitled "Questions of a Reading Worker" (also the title of a poem by Bertolt Brecht) and his bronze sculpture "Reading Worker" was installed in the library's fountain courtyard in 1961. The change from the library's tradition of serving primarily researchers and scholars to becoming a research library that also served the general public in a communist state required the ideological retraining of the staff (Dosa, 1974, p. 167). The Stasi, the East German secret police, even had the library bugged (Zimmer, 1990, p. 3).

There was censorship of library materials under the communist government as well. In the years right after the war, the work of the library was supported by the Soviet Military Authority, which ordered the removal of fascist and militaristic literature (Kunze, 1961, p. 56). Whereas the Nazis banned "decadent" and Jewish literature, the Socialist Unity Party, or the SED (Sozialistische Einheitspartei Deutschlands, or Socialist Unity Party of Germany) took anti-socialist literature out of circulation. Training and professional development of staff were directed towards the creation of a socialist work community (Kunze, 1961, p. 71). Party membership was important for advancement under the communist regime, just as it was under the Nazis.

Hoecker wrote to General Eisenhower in August 1945 requesting the return of collections stored in Hattorf in the district of Göttingen in Lower Saxony, but the collections stored in Hattorf and in other places in the American Occupation Zone (Banz Castle in Bavaria, and Laubach Castle and Arnsburg Abbey in Hesse) were sent to Marburg in West Germany. The collections stored in Beuron Abbey in Baden-Württemberg, which was in the French Occupation Zone, were sent to the university library in Tubingen in West Germany. Eisenhower's deputy General Lucius D. Clay did order the return of books that had been evacuated to Tepl in the Sudetenland and transported to Frankfurt am Main by American troops, who discovered them still in freight cars on a railroad siding. The approximately 350,000 volumes were stored in the Offenbach Archival Depot, and when Captain S. J. Pomrenze, the officer in charge of the depot, requested permission to store them elsewhere, Clay had them returned to Berlin (Hill, 1946, pp. 348-349). The American authorities in Berlin received a letter of thanks stating that the returned collections would form the basis for "the reconstruction of the library" (Schochow, 2003, p. 158). The collections housed in Marburg and Tubingen were returned to West Berlin in the 1960s. From 1968 until the reunification of the former Prussian State Library, the library in West Berlin was named the State Library, Prussian Cultural Heritage Foundation. In 1978, it moved into a new building on Potsdamer Straße designed by renowned architect Hans Scharoun. The East German view after the adoption of the law establishing the Prussian Cultural Heritage Foundation in 1957 was that the collections housed in the American and French zones were held in trust and that the West was depriving the German State Library of its rightful ownership of these collections through formal legalistic tricks (Schmidt, 1961, p. 85).

Hill wrote in his 1946 article that he wanted to apprise American scholars who believed that, since the war had ended, they could gain access to German library materials that it could be "at least a few months longer" before the political situation of a divided country that was hindering access to library collections would be solved (p. 327). But access to materials that belonged to the former Prussian State Library would be difficult throughout the Cold War. The West Berlin library's name and its refusal to return the collections to the library in East Berlin extended the Cold War to the now separate libraries with each claiming to be the successor of the Prussian State Library. Bach scholar Robert L. Marshall described the difficulties of conducting research in a divided Berlin:

In Berlin the priceless collection of music manuscripts, including vast numbers of autographs of Bach, Mozart, and Beethoven, is fairly divided 
between East and West. But the catalogue of the manuscripts is still in East Berlin. What this means is that a user must first go to East Berlin-no easy matter itself - to get a call number for the item he needs, and then return to West Berlin to fetch it. The reason for this complication is that East Berlin claims that the manuscripts in West Berlin actually belong to them-since, before the war, they were all housed together on Unter den Linden-and were only separated and dispersed (with many of them remaining in the regions that now constitute West Germany) to avoid destruction during the bombing of the city during the war. Accordingly, there is little disposition on the part of the authorities in the East to cooperate with Western scholars looking for materials in West Berlin; and they refuse to answer inquiries on the phone (1990, p. 2).

And the two libraries were just over a mile apart!

There were, however, notable accomplishments during the time of the East German Democratic Republic. The change of the name from Public Research Library to the German State Library was intended to express the place of the library in German and international librarianship (Kunze, 1961, p. 66). From the start, great attention was paid to the acquisition of material from the Soviet Union and other socialist countries. Emphasis was placed on the natural sciences, technology, medicine, and agriculture. These disciplines were considered important for supporting a socialist society (Kunze, 1961p, 58). The Music Department was championed as an example of the library's international standing. In addition to its extraordinary collections, it cooperated with the RILM project (Répertoire International de Littérature Musicale), was a member of the International Association of Music Libraries (IAML), and participated in international congresses. The German State Library opened a new department for Children's and Youth books in 1951 that included books from all over the world (Kunze, 1961, pp. 62-63). It was a research collection that specialized in historic children's literature and the secondary literature in this area of study. Beginning in 1978, the library expanded the scope of the collection to include original illustrations for children's books and books for young adults.

In the Festschrift for the three-hundredth anniversary of the library, Kunze (1961) mentions three things that needed to be accomplished in the future: reuniting the almost two million volumes of the former Prussian State Library that were held in the West with the collections in East Berlin, the restoration of the domed reading hall destroyed in an air raid, and the application of technology and automation to the library's operations. (p. 75). These three goals would not be accomplished during the fifty-year history of the German Democratic Republic. By the 1980s, the economic problems of the German Democratic Republic were causing great difficulties for the German State Library in East Berlin. Librarianship in East Germany was outdated and ideologically restricted. Priceless volumes were stored in four concrete book towers for lack of space, and many books were moldy and unsalvageable. There was no electronic data processing for basic library functions, such as cataloging and circulation. The library lacked bookbinding capabilities for the preservation of the collections. Technology for information exchange and access to international databases was absent. Telephone lines were not stable and did not support such access (Zimmer, 1990, p. 2).

The day before the fall of the Berlin Wall on November 9, 1989, the president of the East German Library Association Karl-Heinz Jügelt presented the association's position on the renewal and reform of the library and information science system in East Germany to the East German Council of Ministers and the Central Committee of the SED, the East German Communist Party (Bibliotheksverband der Deutschen Demokratischen Republik, 1990). The 
document began with a statement on the importance of the nation's library and information system to the progress of all areas of their socialist democracy. Despite the best efforts of all types of libraries, the growing demands from the fields of scholarship, education, and culture were not being satisfactorily met.

The document enumerated problems and issues that needed to be addressed to meet demands and modernize the library and information science system in the German Democratic Republic. Technology, equipment, furnishings, space, and buildings were at the top of the list. The technological capabilities of East German libraries were not at the same level as in Western countries, especially with regard to online catalogs, databases, and fax service. There was also the need for software and standards. As a consequence of these problems, East German libraries could not take part in international cooperative efforts and were falling further and further behind. In addition, foreign subject literature and data storage media were not sufficiently available or not at all available. The position paper stated that unless these problems were addressed, the result would be the inability of East Germany to compete internationally. The document called for increased financial support from the East German government and criticizes the low value placed on libraries by the SED. There is also mention of the low pay of librarians, which was behind that of other specialists. The report notes the urgent need for restoration, conservation, and preservation of rich cultural heritage collections and the necessary personnel, financial, and technical means to pursue UNESCO's appeal for national preservation programs. In 1990, the year of German reunification, Dieter Schmidmaier, the last director of the German State Library in East Berlin, wrote a position paper on the status and place of that library in a renewed East German library system that echoed the problems and issues described in the position paper published by the East German Library Association (Schmidmaier, 1990).

\section{THE AFTERMATH OF THE SECOND WORLD WAR AND THE COLD WAR}

Today, the Berlin State Library remains greatly affected by events that occurred more than three-quarters of a century ago. Dominik Sackmann wrote in 1998: "The past is present. Nazism, the Shoah, and two world wars continue to reverberate even at the end of the twentieth century" (Sackmann, 1998, p. 160). That statement is still true almost two decades into the twenty-first century. The destruction of Europe's cultural heritage and the confiscation and looting of cultural treasures and artifacts by the Nazis continue to be important issues more than seven decades after the end of the Second World War. Books such as The Rape of Europa (Nicholas, 1994), The Monuments Men (Edsel \& Witter, 2010), and The Lady in Gold (O'Connor, 2012) attest to the interest in these topics. A recent addition to the list of works is Stolen Words: The Nazi Plunder of Jewish Books by Mark Glickman (2016). Rabbi Glickman recounts how the Nazis raided homes, libraries, and other institutions to amass millions of books and other materials owned by Jewish citizens.

\section{The Fate of the Treasures Evacuated from the Prussian State Library}

Some of the collections belonging to the Prussian State Library that were evacuated during the war became the spoils of war. Collections that were stored in areas that after the war became part of Poland have not been returned, and books transported out of Germany and the storage depots by the Red Army and distributed to libraries in Eastern Europe have also not been returned. Many of the Prussian State Library's greatest treasures were evacuated to Grüssau Abbey (today Krzeszów Abbey in Lower Silesia, Poland) in 1944 and transported to Kraków 
in 1946. For over thirty years the fate of the collections stored in Grüssau Abbey was unknown. The fear was that these collections were destroyed in the war. More than 500 cases from the library's Manuscript Department containing manuscripts of some of the world's most important composers were stored in Grüssau. The treasure trove of music manuscripts included almost a quarter of the known surviving Mozart manuscripts, as well as manuscripts of Bach, Beethoven, Brahms, Haydn, Schubert, Schumann, Mendelssohn, Meyerbeer and others (Lewis, 1981, p. 37). The presumed loss of so many Mozart manuscripts had a profound impact on the publication of the Neue Mozart Ausgabe (Mozart, 1955-1991), the new edition of the complete works of Mozart. The authoritativeness and completeness of this new definitive edition of Mozart's works were threatened from the outset (Lewis, 1981, pp. 95-96).

The Varnhagen Collection, also stored in Grüssau, was important for the study of early German Romantic literature. The collection originally belonged to Karl Varnhagen von Ense and contained the papers of his wife Rahel Varnhagen, Goethe, Wilhelm von Humboldt, the Schlegel brothers, Heine, Hegel, Fichte and others (Hertz, 1981, p. 224). In the preface to her biography of Rahel Varnhagen, Hannah Arendt mentions that the extensive correspondence between Rahel Varnhagen and Pauline Wiesel contained in the Varnhagen Collection was the greatest loss to her book, because the letters were the most important source on Rahel Varnhagen's life after her marriage. Arendt also intended to include some letters and diaries in notes and in an appendix to her biography (1974, pp. iii-xiv). Among the other treasures stored in Grüssau were natural science watercolor paintings and oil paintings from a seventeenthcentury Dutch expedition to Brazil that Count Johann Moritz von Nassau-Siegen gave to Friedrich Wilhelm, the Great Elector of Brandenburg, as a gift in 1652 (Lewis, 1981, pp. 2526). Only sixty-two of the approximately two thousand drawings and paintings important to the fields of ethnology, zoology, and botany had been photographed (Whitehead, 1976, p.11). Manuscripts from the Oriental and East Asian Department, genealogical collections, personal papers, etc. were also included in the materials stored in Grüssau (Schmidt, 1961, p. 82). The mystery was finally solved in 1977 when it became publicly known that the Grüssau collections were in the Jagiellonian Library in Kraków.

Nigel Lewis (1981) tells the fascinating story of the evacuated Grüssau treasures in his book Paperchase: Mozart, Beethoven, Bach...The Search for their Lost Music. When it became known that these valuable collections were in the Jagiellonian Library, Poland's First Secretary Edward Gierek ceremoniously returned the manuscripts of Mozart's Magic Flute, the orchestral score (minus the choral finale) of Beethoven's Ninth Symphony, and five other manuscripts by Mozart, Bach, and Beethoven to East German General Secretary Erich Honecker after the ratification of a friendship treaty in May 1977. The remainder of the collections from Grüssau is still in the Jagiellonian Library. Werner Schochow (2003) has written an account based on primary sources of the evacuation and storage of the Prussian State Library's collections and the fate of the collections in the various storage depots after the war.

\section{Overview of the Political Situation}

Poland suffered large-scale destruction and plunder of its cultural property during the Nazi occupation. The Polish government-in-exile and the Polish underground in occupied Poland coordinated efforts to register this cultural looting for future compensation demands. Karol Estreicher, an art historian and bibliographer at the Jagiellonian University, was the leader of this effort. Estreicher was chiefly responsible for the publication of Cultural Losses of Poland (Estreicher, 1944). It was an index of losses suffered by cultural institutions that could be used in determining compensation and restitution after the war (Sroka, 2012, p. 9). The Soviet Union also experienced severe cultural losses during the German invasion. In the 1990s 
there were still strong sentiments about the war. The Russians too wanted compensation, even if it meant selling what was termed "trophy literature" on the antiquarian market (Sutter, 1994, p. 408). Similarly, the Polish viewpoint in the 1990s concerning the collections of the former Prussian State Library was that they are in the Jagiellonian Library as a result of the war that Poland did not start (Sroka, 2007, p. 660). Marek Sroka summarizes the stalemate between Poland and Germany with regard to the collections still in the Jagiellonian Library:

The fall of communism and the unification of Germany did indeed change the character of negotiations. Poland was no longer negotiating with one of two German states that were often in competition with each other. Moreover, the Polish government no longer had to be concerned that its foreign policy follow the dictates of the Soviet Union as it had for the previous fifty years. Paradoxically, this may have made future negotiations more challenging as Poland and East Germany (now the Federal Republic of Germany) were conducting their foreign policy as sovereign states for the first time since the end of World War II (2007, p. 659).

Thus, the greatest impediment to the return of collections still held in East European libraries remains the question of war reparations.

\section{Treasures Returned, Treasures Retained}

The Prussian State Library experienced two kinds of expropriation of books and collections during the Third Reich and after the war. Whereas collections originally belonging to the former Prussian State Library became war plunder, the Nazis also confiscated books and collections from individuals and institutions and distributed them to German libraries. Cornelia Briel (2013) published an important study of the Prussian State Library's role in the Nazi confiscation of books. Since the Prussian State Library was central to the German library system, it was heavily involved in the acquisition and distribution of library materials stolen by the Nazis (Briel, 2013, p. 303).

The Washington Conference on Holocaust-Era Assets sponsored by the U.S. State Department and the U.S. Holocaust Memorial Museum in 1998 provided the impetus to investigate the issue of confiscated books still in the library's collections. In December 1999, the German federal government, states, and municipalities issued a joint declaration on the discovery and return of property confiscated as a result of Nazi persecution and still in the possession of public institutions (Kultusministerkonferenz, Germany, 1999). In February 2001, the Federal Commissioner for Culture and Media issued a set of recommendations that required libraries to search for Nazi-confiscated materials in their collections (Germany, Beauftragte der Bundesregierung für Kultur und Medien, 2001). This required a systematic analysis of the provenance of books that may have been confiscated by the state and National Socialist organizations from Jewish citizens and institutions, Communists, Social Democrats, Freemasons, church establishments, etc. and integrated into the collections of research and public libraries (Bödeker \& Bötte, 2008, p. 6). As the successor to the Prussian State Library, the Berlin State Library has endeavored to identify books in its collection that were acquired directly or indirectly through Nazi confiscation, research their provenance, and return them to their rightful owners or their heirs. The quest to determine provenance and to restitute stolen property includes searching the Yad Vashem Names Database. Books that are possible Nazi stolen property have clues to their provenance documented in the online catalog and are listed in the International Database of Lost Art in Magdeburg.

Examples of success include the return of the private library of Rabbi Leo Baeck to his granddaughter in New York in April 2006 and the return of a collection of music archival 
materials that belonged to the pianist Arthur Rubenstein to three of his children on May 5, 2007 in New York (Hollender, 2006, pp. 32-37)). Confiscated or stolen books were sometimes inventoried as gift books (Pudler, 2008, p. 149 n.8). An examination of the records for gifts enabled the Berlin State Library to return 330 books confiscated from the Potsdam Masonic Lodge (Schneider-Kempf, 2013, p. 8). In 2010, the Berlin State Library returned two volumes printed in the seventeenth century that came from the library of Wilhelm-Friedrich, count of Lynar, who was hanged as a result of his participation in the July 20, 1944 failed attempt on Hitler's life and whose family was dispossessed by the Nazis. (Staatsbibliothek zu BerlinPreußischer Kulturbesitz, 2010, p. 16).

With regard to the issue of collections of the former Prussian State Library still held by other libraries, the General Director of the Berlin State Library Barbara Schneider-Kempf (2014) reports that there has recently been some cooperation between the Berlin State Library and the Jagiellonian Library with digitization projects (p. 7). The strengthening of such partnerships with Eastern European libraries is part of the Berlin State Library's strategic plan, as is research into the history and provenance of books stolen by the Nazis (Staatsbibliothek zu Berlin-Preußischer Kulturbesitz, 2015). Since 2009, the library has participated in a series of dialogues with Russian librarians on the return of collections evacuated during the war and transported to the Soviet Union by the Red Army and on the return of books taken from Russian libraries during the German invasion (Schneider-Kempf, 2013, pp. 2-3).

\section{THE BERLIN STATE LIBRARY REUNITED AND RESTORED}

In accordance with the German unification treaty, the German State Library in East Berlin was placed under the trusteeship of the Prussian Cultural Heritage Foundation in 1990 and reunited with the State Library, Prussian Cultural Heritage Foundation on January 1, 1992. The conception for the reunification was one library in two houses. It was seen as a way to merge the libraries rationally, economically, and as quickly as possible (Cope, 1999, p. 44). Neither building could house the collections with room left for future growth and adequate space for staff and users. Moreover, the two buildings symbolized the old and the modern Berlin and were located in the heart of the city near three universities and research and cultural institutions. No alternative to the concept of one library in two houses was considered viable by concerned parties, staff, and users (Jammers, 1997, p. 43). But the costs of restoring the old building led the Office of the Federal Auditor General to question the concept (Cope, 1999, p. 45). The general director of the East Berlin library, Dieter Schmidmaier, feared that the high cost of renovations to the war-damaged building on Unter den Linden would place the library low on the list of priorities because of the need to renovate so many public buildings in East Berlin (Eberhart, 1990, p. 616-617). R. L. Cope blames these problems on the SED's bad record in curating the cultural assets taken over from the former Prussian state. The library on Unter den Linden was in many ways left in the same condition as it was when the war ended in 1945, and the reunited library was facing the kinds of problems not dealt with in West Germany since the time of postwar reconstruction. (Cope, 1999, p. 54). The alternative of locating all the collections in the Scharoun building on Potsdamer Straße was examined (Cope, 1999, p. 46), but it was not considered feasible based on cost, functional considerations, and capacity (Jammers, 1997, pp. 46-47). The final costs would eventually need to include the reconstruction of the central reading room destroyed in the war and the demolition of the book storage towers built where the reading room would be located. It should also be kept in mind that the time span between the reunification treaty on October 3, 1990 and the merger of the two libraries on January 1, 1992 allowed a little more than a year for planning the merger. 
As originally planned, the library building on Unter den Linden was to be a library for historical research and the building on Potsdamer Straße a modern research and lending library and information center, but several departures from the concept were necessary for practical reasons (Jammers, 1997b, pp. 294-296). The library created nine special collections. The building on Unter den Linden houses music, maps, and a new department for historical prints. The Manuscripts Department, the East European Department, the Oriental Department, and the East Asian Department are in the library on Potsdamer Straße. The combined serials collections from both libraries formed a new department located in a storage unit in Berlin Westhafen. The Children's and Young Adults' Department is temporarily housed in Westhafen.

The planned distribution of books between the two houses was based on publication dates. Since the building on Unter den Linden was to be a library for historical research, books published from 1501 until 1955 were to be housed there, and books published from 1956 on would be housed in the building on Potsdamer Straße (Landwehrmeyer, 1993, pp. 55-57). One complicated problem that needed to be dealt with at the outset was the different catalogs. Although the public catalog of the Prussian State Library had been destroyed, the East Berlin library possessed a catalog of the prewar collection with abridged entries that was intended for internal use. This catalog included items that were in West Berlin, lost, or destroyed. The West Berlin library had no catalog of the prewar collection and had to recatalog the prewar items in its collections. The retrospective conversion of the card catalog and the creation of an online catalog was an imperative (Landwehrmeyer, 1993, pp. 57-60). There were cards in an old form of German handwriting that many staff and users could not decipher. The cataloging records dating before 1890 were not standardized, but later entries followed the Prussian Instructions. Identifying duplicate records in the parallel catalogs was an important consideration. The project resulted in an online catalog that greatly improved access over the handwritten cards and made the holdings of the library available on the Internet (Hartwig, 2006).

The reunification of the East and West Berlin successors of the Prussian State Library was not without personnel issues and problems. The cultural differences between East and West Berliners that was common in Berlin at the time was a source of friction and misunderstanding. Different mindsets had developed over five decades of separation. In a contemporary account of the reunification of the libraries, a West Berliner stated that in East Berlin librarianship was practiced as the West Berliners did thirty years previously and that the East Berliners needed to become familiar with the American style of librarianship. An East Berliner felt slighted by the perceived attitude of superiority exhibited by the West Berliners and noted that they in East Berlin ran a national library with far less means than in the West. (Rückert, 1991, p. 4). To make matters worse, the East Berliners received unequal pay for the same work. Different processes and areas of responsibility needed to be integrated and duplicate work eliminated. Departments needed to be combined and restructured. The staff of the combined serials department faced the fundamental question of what was considered a serial for the purposes of the new department (Zeller, 1999, p. 88). The new organizational structure was primarily that of the West Berlin library, because there were features of the library in East Berlin that were specific to the communist system (Jammers, 1997a, pp. 4041). Jammers holds that the staff deserve recognition for what was accomplished during the difficult transition (Jammers, 1997b, p. 40). Cope hopes for a better future for the library, because "the achievements of its staff over earlier decades merit no less" (Cope, 1999, p. 55).

Since the reunification of the library, the call for the application of advanced technology and national and international cooperation made by Dieter Schmidmaier and others has been met in full measure. The many digitization projects undertaken by the Berlin State Library evidence the library's creative use of technology and show that it is both a partner and a leader 
at the international level. The library has been recognized by other nations and entities, which substantiates its worldwide reputation.

The field of East Asian scholarship is one area in which the Berlin State Library has had a significant impact from its founding in the seventeenth century. Guido Auster (1961) and Werner Knopp (1999) describe the development of the library's East Asian collections. The library has continued this tradition into the current century by dedicating itself to the acquisition of digital resources in East Asian studies. One of the first achievements in this area was the award-winning Internet Guide for Chinese Studies maintained by the Sinological Institute at Leiden University and supported by the Berlin State Library, Heidelberg University, and the German Research Foundation. The Berlin State Library has developed virtual subject libraries, which Ann Lipp has described as the digital face of the library's special collections. Lipp highlighted CrossAsia, the virtual subject library for East and South Asia (Lipp, 2011, p. 59). In 2009, Minister of General Administration of Press and Publication Liu Binjie presented General Director Barbara Schneider-Kempf with the gift from the Chinese government of an expensive database in Chinese studies, which was made available on CrossAsia and which greatly increased the library's offerings of electronic reference sources and newspapers from China. With this gift, the Chinese government recognized and supported the library's long history of developing its East Asian collections (Chinesische Datenbank, 2010, p. 86). The Berlin State Library began digitizing material from its East Asian collections in 2009. The project to digitize East Asian materials is a good example of the library's efforts at international cooperation. The library collaborated with the Jagiellonian Library on this project, and the East Asian collections of the former Prussian State Library now housed in Kraków were reunited virtually with the collections in Berlin (Siebert, 2011, p. 61).

The "Europeana 1914-1918" digital collection is an example of the international leadership role of the Berlin State Library. As part of the centenary commemoration of World War I, the library led a consortium of ten national libraries from eight European countries, including the Bibliothèque nationale de France and the British Library, and two additional partners in the development of a common virtual collection on World War I comprised of letters, diaries, photographs, music, newspapers, and other items from the special collections of national libraries. The online collection of about 400,000 sources presents a comprehensive overview of life on the front and in the homeland. The Berlin State Library contributed 6800 digital objects to the collection.

\section{CONCLUSION}

Karol Estreicher, the proponent of restitution for Poland's cultural losses, wrote in his diary in 1940 that the cultural heritage of a nation is essential for its survival (Sroka, 2012, p. 6, n.8). UNESCO established the Memory of the World Programme to raise awareness of the world's documentary heritage and to foster its preservation. The program is an international undertaking based on the concept that documentary heritage is an important part of the world's cultural heritage and transcends political and chronological boundaries. International protection of the world's cultural and documentary heritage is critical to the survival of civilization. UNESCO had already promulgated the Hague Convention in 1954 as a legal instrument that obligates the signees to protect cultural heritage in times of armed conflict.

The ordeal of the Berlin State Library during the past one hundred years demonstrates the importance of the UNESCO Memory of the World Programme. Indeed, the library is included on the list of libraries in Memory of the World: Libraries and Archives Destroyed in the Twentieth Century published by UNESCO (Memory of the World, 1996, p. 10). Damage 
to the cultural property of any nation damages the cultural heritage of all humankind. There is a need for international protection of our global cultural and documentary heritage. To publicize the universality of the program, UNESCO's Memory of the World Programme has established the Memory of the World Register of items that are a part of the cultural heritage of all. The Berlin State Library has four items from its collections on the register: the autographs of Bach's B-minor Mass and Beethoven's Ninth Symphony, a placard of Martin Luther's Ninetyfive Theses printed in Nuremberg in 1517, and the Hebrew Bible used by Luther in making his German translation of the Bible.

Edmund Burke (1791) likened history to a great volume unrolled for our instruction so that we can learn from past errors (p. 209). The story of the Berlin State Library provides an example of how susceptible libraries and other cultural institutions are to social and political upheaval and to the consequences of war. The Berlin State Library was often mentioned together with the Bibliothèque nationale de France and the British Library as three of the greatest libraries in Europe. Seen in this light, the story of the library provides an understanding of the magnitude of harm done to the world's documentary heritage in the twentieth century by the events described above. There is significant and meaningful documentation to tell this story in detail (Schochow, 1989, p. xi). Further research and publication would underscore the importance of the Memory of the World Programme. Publications in English would reach a wider audience. In Berlin, the old library building has been restored, but the debates about cultural loss, war reparations, and restitution still affect the library (Sroka, 2007, p. 651).

The former Prussian State Library, now the Berlin State Library-Prussian Cultural Heritage Foundation, is famous for its rich collections, exceptional services to its users and to the international community of libraries and scholars, and for its highly qualified and accomplished staff. It is once again one of the world's preeminent research libraries (Staatsbibliothek zu Berlin--Preußischer Kulturbesitz, 2015, p. 7). Its survival is a testimony to the importance placed upon research libraries as cultural and documentary heritage institutions. The Berlin State Library is also a symbol of a reunited Germany. The building on Unter den Linden and the Scharoun building on Potsdamer Straße are registered architectural monuments. Its two houses, once in two different worlds separated by a wall, are now united in the world of books and knowledge (Garber, 1997, pp. 87-88).

\section{References}

Arendt, H. (1974). Rahel Varnhagen: The Life of a Jewish Woman (Rev. ed.), (R. Winston \& C. Winston, Trans.). New York: Harcourt Brace Jovanovich.

Auster, G. (1961). Die orientalische Abteilung [The Oriental Department]. In H. Kunze, W. Dube \& G. Fröschner (Eds.), Deutsche Staatsbibliothek: 1661-1961 (pp. 275-317). Leipzig: VEB Verlag für Buch-und Bibliothekswesen.

Bibliotheksverband der Deutschen Demokratischen Republik. (1990). Für eine Reform des Bibliotheks- und Informationswesens und des Bibliotheksverbandes der DDR [For a reform of the library and information system and the Library Association of the GDR]. Zentralblatt für Bibliothekswesen 104(1), 1-3.

Bödeker, H. E. \& Bötte, G.-J. (2008). NS-Raubgut, Reichstauschstelle und Preußische Staatsbibliothek: Skizze einer Problemstellung [NS-stolen property, the State Exchange Office, and the Prussian State Library: Sketch of a problem situation]. In H. E. Bödeker \& G.-J. Bötte (Eds.), NS-Raubgut, Riechstauschstelle und Preußischer Staatsbibliothek: Vorträge des Berliner Symposiums am 3. Und 4. Mai 2007 (pp. 1-7). Munich: K. G. Saur. 
Breslau, R. (Ed.). (1995). Verlagert, verschollen, vernichtet...Das Schicksal der im 2. Weltkrieg ausgelagerten Bestände der Preußischen Staatsbibliothek [Moved, missing, destroyed...the fate of the collections of the Prussian State Library evacuated in the Second World War]. Berlin: Staatsbibliothek zu Berlin-Preußischer Kulturbesitz.

Briel, C. (2013). Beschlagnahmt, erpresst, erbeutet: NS-Raubgut, Reichstauschstelle und Preußische Staatsbibliothek zwischen 1933 und 1945 [Confiscated, extorted, carried off: NS-stolen property, the State Exchange Office, and the Prussian State Library between 1933 and 1945]. Bödeker, H. E. \& Bötte, G.-J. (Eds.). Berlin: Akademie Verlag.

Burke, E. (1791). Reflections on the Revolution in France, and on the proceedings in certain societies in London relative to that event. In a letter intended to have been sent to a gentleman in Paris. London: printed for J. Dodsley, in Pall-Mall.

Chinesische Datenbank [Chinese database]. (2010). Bibliotheksmagazin 1, 86. Retrieved from:http://staatsbibliothekberlin.de/fileadmin/user_upload/zentrale_Seiten/ueber_uns /pdf/Bibliotheksmagazin/2010-1_web.pdf

Cope, R. L. (1999). Pursuing library visions or chimeras in Berlin? A review of the future of the State Library in Berlin. Australian Academic \& Research Libraries 30(1), 40-56. doi:10.1080/00048623.1999.10755076

Dosa, M. L. (1974). Libraries in the political scene. Westport, Conn.: Greenwood Press.

Eberhart, G. M. (1990). The editor goes East: A visit to four very different libraries in Central Europe. College \& Research Libraries News 51(7), 616-620.

Edsel, R. M. \& Witter, B. (2010). The Monuments Men: Allied heroes, Nazi thieves, and the greatest treasure hunt in history. New York: Center Street.

Estreicher, Karol (Ed.) (1944). Cultural losses of Poland: Index of Polish cultural losses during the German occupation, 1939-1944. London: Publisher not identified.

Garber, K. (1997). Die Weltkultur des Buches in zwei gleich imponierenden Häusern im Herzen Berlins [The world culture of the book in two equally imposing houses in the heart of Berlin]. In G. Spitzer (Ed.), Die Staatsbibliothek Unter den Linden: Ein Kolloquium in der Staatsbibliothek zu Berlin am 11. Juni 1997 (pp. 85-89). Frankfurt am Main: Vittorio Klostermann.

Germany. Beauftragte der Bundesregierung für Kultur und Medien. (2007). Handreichung zur Umsetzung der "Erklärung der Bundesregierung, der Länder und der kommunalen Spitzenverbände zur Auffindung und zur Rückgabe NSverfolgungsbedingt entzogenen Kulturgutes, insbesondere aus jüdischem Besitz” vom Dezember 1999: vom Februar 2001, überarbeitet im November 2007 [Guide to the implementation of the "Statement of the Federal Governemnt, the States and the leading municipal organizations on the discovery and restitution of stolen cultural property related to NS-persecution, especially from Jewish possesion," from December 1999: from February 2001, revised in November 2007]. Retrieved from http://www.bibliotheksverband.de/fileadmin/user_upload/DBV/themen/ German_Handreichung.pdf

Glickman, M. (2016). Stolen words: The Nazi plunder of Jewish books. New York: Jewish Book Council.

Hartwig, F. (2006). Wie kommen die Karteikarten in den StaBiKat? Die Retrokonversion des alten alphabetischen Zettelkataloges [How do the catalog cards get into StaBiKat? The retrospective conversion of the old alphabetical card catalog]. Bibliotheksmagazin 2, 9-13. Retrieved from http://staatsbibliothek-berlin.de/fileadmin/user_upload/ zentrale_Seiten/ueber_uns/pdf/Bibliotheksmagazin/bibliotheksmagazin_0602.pdf

Hertz, D. (1981). The Varnhagen Collection is in Krakow. The American Archivist 44(3), 223-228. 
Hill, R. S. (1946). The former Prussian State Library. Notes, ser. 2, 3/4, 327-350; 404-410. Retrieved from http://www.jstor.org/stable/pdf/890393.pdf

Hollender, M. (2006). Aus den Privatbibliotheken von Leo Baeck und Arthur Rubenstein: Die Staatsbibliothek restituiert NS-Raubgut an die Erben der jüdischen Eigentümer [From the private libraries of Leo Baeck and Arthur Rubenstein: The State Library returns NS-stolen property to the heirs of Jewish owners].

Bibliotheksmagazin 3, 32-37. Retrieved from http://staatsbibliothek-berlin.de/ fileadmin/user_upload/zentrale_Seiten/ueber_uns/pdf/Bibliotheksmagazin/bibliotheks magazin_0603.pdf

Jammers A. (1997a). Die Entwicklung der Staatsbibliothek zu Berlin nach ihrer Vereinigung [The development of the Berlin State Library after its unification]. In G. Spitzer (Ed.), Die Staatsbibliothek Unter den Linden: Ein Kolloquium in der Staatsbibliothek zu Berlin am 11. Juni 1997 (pp. 37-48). Frankfurt am Main: Vittorio Klostermann.

Jammers, A. (1997b). Die Staatsbibliothek zu Berlin in schwierigen Zeiten: Eine Konzeption, aber noch keine endgültige Standortfestlegung [The Berlin State Library in difficult times: A conception but still no final definition of its position]. Zeitschrift für Bibliothekswesen und Bibliographie 44(3). 281-301.

Knopp, W. (1999). Preußens Könige und ihre Bibliothek [Prussia's kings and their library]. In A. Jammers (Ed.), Schätze wieder vereint: Die Zusammenführung der historischen Sonderabteilungen der Staatsbibliothek zu Berlin (pp. 108-123). Berlin: Staatsbibliothek zu Berlin--Preußische Kulturbesitz.

Kress-Adams, H. \& Adams, G. M. (2013). Das Licht als Moderator der Architecture [Light as moderator of architecture]. In Staatsbibliothek zu Berlin--Preußischer Kulturbesitz, Der neue Lesesaal der Staatsbibliothek zu Berlin: Kultur, Architektur, Forschung (pp. 51-54). Berlin: Nicolaische Verlagsbuchhandlung, Kultusministerkonferenz, Germany. (1999). Erklärung der Bundesregierung, der Länder und der kommunalen Spitzenverbände zur Auffindung und zur Rückgabe NSverfolgungsbedingt entzogenen Kulturgutes, insbesondere aus jüdischem Besitz (Beschluss der Kultusministerkonferenz vom 9. Dezember 1999) [Statement of the Federal Government, the States and the leading municipal organizations on the discovery and restitution of stolen cultural property related to NS persecution, especially from Jewish possession (resolution of the Conference of the Ministers of Education on 9 December 1999)]. Retrieved from http://www.kmk.org/fileadmin/Dateien/pdf/PresseUndAktuelles/2001/kultgut.pdf

Kunze, H. (1961). Demokratisierung und sozialistische Umgestaltung [Democratization and socialist remodeling]. In H. Kunze, W. Dube \& G. Fröschner (Eds.), Deutsche Staatsbibliothek: 1661-1961 (pp. 49-76). Leipzig: VEB Verlag für Buch-und Bibliothekswesen.

Kunze, H. \& Dube, W. (1961). Zur Vorgeschichte der Deutschen Staatsbibliothek: Die Entwicklung der Bibliothek von ihrer Gründung bis zum Zusammenbruch Preußens (1659/61 bis 1806) [On the past history of the German State Library: The development of the library from its founding until the collapse of Prussia (1659/61 until 1806)]. In H. Kunze, W. Dube \& G. Fröschner (Eds.), Deutsche Staatsbibliothek: 1661-1961 (pp. 1-47). Leipzig: VEB Verlag für Buch-und Bibliothekswesen.

Landwehrmeyer, R. (1993). The Berlin State Library/Staatsbibliothek zu Berlin: A library in transition. Alexandria 5(1), 53-69.

Lehmann, K.-D. (1997). Die Staatsbibliothek zu Berlin im Kreis der grossen National-und Staatsbibliotheken [The Berlin State Library in the circle of the great national and state libraries]. In G. Spitzer (Ed.), Die Staatsbibliothek Unter den Linden: Ein 
Kolloquium in der Staatsbibliothek zu Berlin am 11. Juni 1997 (pp. 59-65). Frankfurt am Main: Vittorio Klostermann.

Lewis, N. (1981). Paperchase: Mozart, Beethoven, Bach...The search for their music. London: H. Hamilton.

Leyh, G. (1947). Die deutschen wissenschaftlichen Bibliotheken nach dem Krieg [German research libraries after the war]. Tubingen: J. C. B. Mohr.

Lipp, A. (2011). Von der Bibliotheksförderung zur Förderung wissenschaftlicher Informationsstruktur: Das Förderspektrum der Deutschen Forschungsgemainschaft und die Projekte der Staatsbibliothek zu Berlin zwischen Tradition und Innovation [From the sponsorship of libraries to the sponsorship of a scholarly information structure: The spectrum of the German Research Foundation's sponsorship and the projects of the Berlin State Library between tradition and innovation]. In B. Schneider-Kempf (Ed.), Für Forschung und Kultur: Sonderausgabe "BibliotheksMagazin: Mitteilung aus den Staatsbibliotheken in Berlin und München" anlässlich des 350. Geburtstag der Staatsbibliothek zu Berlin--Preußischer Kulturbesitz, 2011, 58-59. Retrieved from http://staatsbibliothek-berlin.de/ fileadmin/user_upload/zentrale_Seiten/ueber_uns/pdf/Bibliotheksmagazin/sbb350.pdf Marshall, R. L. (1991). A tale of two cities-and three libraries. Newsletter of the American Bach Society, 1-2.

Memory of the World: Lost memory--libraries and archives destroyed in the twentieth century. (1996). Prepared for UNESCO on behalf of IFLA by Hans van der Hoeven and on behalf of ICA by Joan van Albada. Paris: UNESCO. Retrieved from http://unesdoc.unesco.org/images/0010/001055/105557e.pdf

Mommsen, T. (1905). Über die Königliche Bibliothek [On the Royal Library]. Reden und Aufsätze (pp. 215-227). Berlin: Weidmannsche Buchhandlung.

Mozart, W. A. (1955-1991). Neue Mozart Ausgabe sämtlicher Werke. International Mozarteum Foundation, Salzburg (Ed.). Kassel: Bärenreiter.

Nicholas, L. H. (1994). The rape of Europa: The fate of Europe's treasures in the Third Reich and the Second World War. New York: Knopf.

O’Connor, A.-M. (2012). The Lady in gold: The extraordinary tale of Gustav Klimt's masterpiece, Portrait of Adele Bloch-Bauer. New York: Knopf.

Pudler, H. (2008). Geschäftsgänge zur Restitution von NS-Raubgut in der Staatsbibliothek zu Berlin: Ein Bericht aus der Praxis [Procedures for the restitution of NS stolen property in the Berlin State Library: A report from practice]. In H. E. Bödeker \& G.J. Bötte (Eds.), NS-Raubgut, Riechstauschstelle und Preußischer Staatsbibliothek: Vorträge des Berliner Symposiums am 3. Und 4. Mai 2007 (pp. 147-158). Munich: K. G. Saur.

Reichmann, F. (1962). Three hundred years of the Prussian State Library [Review of the book Deutsche Staatsbibliothek: 1661-1961, H. Kunze, W. Dube \& G. Fröschner (Eds.)]. The Library Quarterly 32(3), 225-230. Retrieved from http://www.jstor.org/stable/4305252

Rückert, S. (1991, June 7). Die Hochzeit der Bücher [The wedding of the books]. Zeit Online. Retrieved from: http://www.zeit.de//24/die-hochzeit-der-buecher

Richards, P. S. (1984). “Aryan Librarianship”: Academic and research libraries under Hitler, The Journal of Library History (1974-1987) 19(2), 231-258. Retrieved from http://www.jstor.org/stable/25541502

Sackmann, D. (1998). Classical music: A state secret (S. Gillespie, Trans.), The Musical Quarterly 82, 160-189. Retrieved from http://www.jstor.org/stable/742239

Schmidmaier, D. (1990). Positionspapier zur Stellung der Deutschen Staatsbibliothek in 
einem erneuerten Bibliothekswesen der DDR [Position paper on the place of the German State Library in a renewed library system of the GDR]. Bibliotheksdienst 24(1), 155-162.

Schmidt, W. (1961). Die Verlagerung der Bestände im Zweiten Weltkrieg und ihre Rückführung [The relocation of collections in the Second World War and their return]. In H. Kunze, W. Dube \& G. Fröschner (Eds.), Deutsche Staatsbibliothek: 1661-1961 (pp. 77-86). Leipzig: VEB Verlag für Buch-und Bibliothekswesen.

Schneider-Kempf, B. (2012). Jahresbericht der Bibliothek: Kurzbilanz 2012/Ausblick 2013 [Yearly report of the library: brief balance sheet 2012/outlook 2013]. Retrieved from http://staatsbibliothek-berlin.de/fileadmin/user_upload/zentrale_Seiten/ ueber_uns/pdf/kurzbilanz12_ausblick13.pdf

Schneider-Kempf, B. (2013). Kurzbilanz 2013/Ausblick 2014 [Brief balance sheet 2013/outlook 2014]. Retrieved from http://staatsbibliothekberlin.de/fileadmin/user_upload/zentrale_Seiten/ ueber_uns/pdf/kurzbilanz13_ausblick14.pdf

Schneider-Kempf, B. (2014). Schaut auf dieser Bibliothek [Look at this library]. Interviewed by S. Hoff. Bibliotheksmagazin 9(3), 3-8. Retrieved from http://staatsbibliothekberlin.de/fileadmin/user_upload/zentrale_Seiten/ueber_uns/pdf/Bibliotheksmagazin/B ibliotheksmagazin_3-2014.pdf

Schochow, W. (1989). Die Preußische Staatsbibliothek, 1918-1945: Ein geschichtliche Überblick: mit einem Quellenteil [The Prussian State Library, 1918-1945: A historical overview with a section on sources]. Cologne: Böhlau Verlag.

Schochow, W. (2003). Bücherschicksale: Die Verlagerungsgeschichte der Preußischen Staatsbibliothek: Auslagerung, Zerstörung, Entfremdung, Rückführung, dargestellt aus den Quellen [The fates of books: The history of the relocation of the Prussian State Library: Evacuation, destruction, estrangement, return, prepared from the sources]. Berlin: De Gruyter.

Siebert, M. (2014). Digitalisierung "ostasiatisch": Besonderheiten und Herausforderung ostasiatischer Materialien in westlichen Digitalisierungsprojekten [Digitization "East Asian": Specificities and challenges of East Asian materials in Western digitization projects]. Bibliotheksmagazin 1, 57-63. Retrieved from http://staatsbibliothekberlin.de/fileadmin/user_upload/zentrale_Seiten/ueber_uns/pdf/Bibliotheksmagazin/B M_1-14.pdf

Sroka, M. (2007). The music collection of the former Prussian State Library at the Jagiellonian Library in Kraków, Poland: Past, present, and future developments. Library Trends 55(3), 651-664.

Sroka, M. (2012). "Nations will not survive without their cultural heritage": Karol Estreicher, Polish cultural restitution plans and the recovery of Polish cultural property from the American Zone of Occupation. The Polish Review 57(3), 3-28. Retrieved from http://www.jstor.org/stable/10.5406/polishreview.57.3.0003

Staatsbibliothek zu Berlin-Preußischer Kulturbesitz. (2010). Jahresbericht für das Jahr 2010 [Annual report for the year 2010]. Retrieved from http://staatsbibliothek-berlin.de/ fileadmin/user_uplaod/zentrale_Seiten/ueber_uns/pdf/Jahresbericht-2010.pdf

Staatsbibliothek zu Berlin-Preußischer Kulturbesitz. (2015). Strategie, 2015-2020 [Strategy, 2015-2020]. Retrieved from http://staatsbibliothek-berlin.de /fileadmin/user_upload/zentrale_Seiten/ueber_uns/pdf/sbb_strategie_2020.pdf

Stimmann, H. (1997). Die Staatsbibliothek Unter den Linden als Bestandteil der Hauptstadtplannung [The State Library on Unter den Linden as a component of the planning of the capital city]. In G. Spitzer (Ed.), Die Staatsbibliothek Unter den 
Linden: Ein Kolloquium in der Staatsbibliothek zu Berlin am 11. Juni 1997 (pp. 7578). Frankfurt am Main: Vittorio Klostermann.

Sutter, S. C. (1994). The fall of the bibliographic wall: libraries and archives in unified Germany. College \& Research Libraries 55(5), 403-411. Retrieved from https://crl.acrl.org/index.php/crl/article/view/14915/16361

Whitehead, P. J. P. (1976). The lost Berlin manuscripts. Notes 33(1), 7-15. Retrieved from http://www.jstor.org/stable/897520

Zeller, J. (1999). Zeitungsabteilung - Nahrung des Geistes im Getreidespeicher: Zur Vorstellung öder Zeitungsabteilung bei der Eröffnungsveranstalltung am 8. Mai '98 [Serials Department - nourishment of the spirit in a granary: By way of an introduction of the remote serials department at the opening ceremony on 8 May '98]. In A. Jammers (Ed.). Schätze wieder Vereint: Die Zusammenführung der historischen Sonderabteilungen der Staatsbibliothek zu Berlin (pp. 81-95). Berlin: Staatsbibliothek zu Berlin--Preußische Kulturbesitz

Zimmer, D. E. (1990, June 29). Bücher im Regen: Ein nationales Notprogram zur Rettung der Bibliotheken der DDR ist nötig [Books in the rain: A national emergency program for the rescue of books in the GDR is necessary]. Zeit Online. Retrieved from http://www.zeit.de/1990/27/buecher-im-regen

\begin{abstract}
About the author
Daniel William Kinney is the subject specialist for German, Italian and Latin in the University Libraries, Stony Brook University. He is also Metadata and Authority Control Librarian. He has an M.A. from Queens College, CUNY, and an M.S.L.S. from the Palmer Graduate School of Library and Information Science, Long Island University.
\end{abstract}

